\title{
Pre-service Science Teachers' Views on Laboratory Applications in Science Education: The Effect of a Two-semester Course
}

\author{
Gonca Harman ${ }^{1}$, Aytekin Cokelez ${ }^{2, *}$, Burckin Dal ${ }^{2}$, Umut Alper $^{3}$ \\ ${ }^{1}$ Department of Elementary Science Education, Faculty of Education, Ondokuz Mayıs University, Turkey \\ ${ }^{2}$ Faculty of Science and Letters, Istanbul Technical University, Turkey \\ ${ }^{3}$ Science Entertainment Centre, Atılım University, Turkey
}

Copyright $(\subset 2016$ by authors, all rights reserved. Authors agree that this article remains permanently open access under the terms of the Creative Commons Attribution License 4.0 International License

\begin{abstract}
The aim of this study was to examine pre-service science teachers' views about laboratory applications in science education and how their views changed through laboratory applications that were carried out for two semesters. 63 (52 females, 11 males) pre-service teachers participated in the study. The study was carried out by using pre-test and post-test design. Data was collected on the differences between the views of pre-service science teachers before and after laboratory courses. For data collection, teachers were given forms including 3 open-ended questions. Data analysis was carried out through qualitative content analysis. The results showed that pre-service teachers defined laboratory as "a place of application", and after laboratory applications, they could give more comprehensive definitions about laboratory. The most popular answers pertaining to the aim of laboratory applications included effective learning, permanent learning, ending rote learning, and better understanding, faster learning and learning with fun. Along with the quality of learning, participants attached importance to the methods and techniques to be utilized in lab setting to reach that desired quality. Their focus was predominantly on visualizing, experimental learning, materializing of the theoretical information through application and observation. Study showed that they mostly attributed the importance of laboratories to the quality of learning and methods were expressed as visualizing, materializing and application, observation and experiment for the quality of learning.
\end{abstract}

Keywords Laboratory Practices, Science Education, Pre-service Science Teacher

\section{Introduction}

Scientific concepts may become concrete in students' minds by means of experiments. It has been understood from the studies carried out so far that conducting experiments and directing students towards scientific studies give students a chance to perceive and recognize the environment, to observe and to build a cause and effect relationship, and to learn by hands-on activities [1]. Besides, empirical science education improves students' self-confidence and motivation; helps them learn about themselves; develops their problem-solving, psychomotor and mental skills; provides meaningful learning; improves analytical thinking skills; and supports the relationship between everyday life and science [2]. In order to understand concepts related to science, students need to be supported by experiments, be actively involved, and establish a relationship between life, themselves and the environment. Experiments not only help students learn more meaningfully, which would provide more permanent learning by contributing to their science process skills, but also help them be productive and creative individuals who are capable of applying theoretical knowledge into practice [3].

Since laboratories constitute one of the basic places to conduct experiments; the expression "I heard, but I forgot. I saw, and I remembered. I did and I understood" by Confucius emphasize the importance of laboratories in science education [4]. Viewed from this perspective, laboratory is an environment where students learn by hands-on activities, living, and gaining first-hand concrete experiences. In his earlier studies, Hodson [5] defined three aims of laboratory applications in science education. The first defined aim of laboratory was to support application of science, thereby enabling students to acquire conceptual and theoretical knowledge. The second one was to learn science through nature and scientific methods. When it comes to the third and last one, here the focus was on performance; in other words to specialize in scientific inquiry. In the light of all these, it can be said that even though the importance of laboratory applications in science education has long been 
acknowledged, recent years witnessed a surging interest in laboratory works and practical work. Literature has revealed that laboratory practices are useful in terms of students' both cognitive and affective development [6]. In terms of cognitive skills, laboratories are places where students learn the concepts, principles, and laws by exploring with experiments [7]. In the process of experimenting, students are involved in observation, measurement, classification, recording data, forming hypotheses and data creation methods, changing and controlling variables. In addition, laboratory practice not only fosters academic achievement [8] but also contributes to meaningful learning by encouraging interpretation of knowledge [2-9]. It has also been found that the majority of students think that experiments are very helpful in their courses and learning by hands-on activities is the best and the most permanent way of learning for them [10]. With respect to affective skills, when laboratory applications were examined, it was seen that successful laboratory practices influenced students' self-esteem, social behavior and relationship with others [9]. In addition, studies support that groups performing a study in the laboratory demonstrate active participation and learning and success, which makes group performance more effective than working individually [11]. It is also known that laboratories encourage students to learn better by motivating them [12]. Moreover, laboratories not only provide a platform for learning by hands-on activities and gathering scientific knowledge in different ways but also contribute to the development of students' psychomotor skills [13]. Therefore, the activities carried out in the laboratory equip students with cognitive, affective, and psychomotor skills such as designing experiments, understanding how theories emerge from experiments, analyzing data, preparing report, discussion, presentation, induction and deduction techniques, developing problem solving skills, team work, time management skills, motivation and self-confidence [14]. Literature revealed that students viewed the laboratory experience as an opportunity for problem-solving on cognitive domains [15].

Practical activity have very important role in science education. Experience and research, were known that students like practical activities and prefer it to other teaching activities.

- Practical activity is to help students extend their knowledge of the natural World.

- Practical activity is to help students develop their ideas and understandings. For students' understanding of scientific ideas are developed, the minds on aspects of practical activity are increased

- Practical activity is to help students develop understandings about the scientific approach to enquiry.

- Practical activity is to help students learn how to use scientific devices.

- Practical activity is to help students follow some standards scientific procedure (s) [52].

As laboratory practices encourage the improvement of skills that are crucial to becoming a scientifically literate individual, these applications are critical for science education. According to Hofstein [16] and Nakhleh [17] laboratory has a complex nature, and laboratory process is affected by various factors. Science teachers have a crucial role in education process [10-18]. In this regard, in order for laboratory practices to continue efficiently, teacher's approach, practice-oriented views and opinions are of paramount importance. In addition, literature suggests that pre-service teachers experience problems about technological pedagogical content knowledge [19]. For this reason, in laboratory-based science teaching, teachers are required to have technological and pedagogical content knowledge and skills in their fields to follow innovations, to supplement their teaching in classrooms and to motivate their students [10].

As suggested by the studies conducted on the laboratory practices, prospective teachers are generally so closely following the instructions in their textbooks and also they tend to express the aim of laboratory applications in line with the textbook [20]. With the promise that science practical work holds, science teacher education has to encourage prospective teachers to understand the nature of practical work and develop strategic ways of conducting it in their classroom teaching. However, practical work is still regarded as one of the most challenging tasks for many elementary science teachers and is practiced infrequently or inefficiently in many science classrooms. Barriers for application inquiry practices in science classes include teachers' beliefs [53], lack of equipment, laboratory safety issues, preparing students for standardized test and official exams and finishing mandated curriculum content within a set time limit [54]. One of the major barriers for application inquiry practices in science classes is teachers' beliefs about teaching, learning and classroom management. Despite that, research about teachers' knowledge and beliefs about inquiry and their classroom practices are still few and inadequate [53].

Literature reviewed above present significant insights into the pre-service science teachers' views about the concept of laboratory, purposes of laboratory practices in science education, and the role and importance of laboratories in science education in Turkey. No matter how important the views of pre-service teachers, especially pedagogically are, they are overvalued. So, the present study seeks to answer following questions:

(1). How do pre-service science teachers define the concept of laboratory? In what ways, does laboratory course have an impact on pre-service science teachers' definition of the concept of laboratory?

(2). What are the opinions of pre-service teachers on the main purposes of laboratory practices in science education? In what ways do laboratory courses have an impact on the views of pre-service science teachers regarding the main purposes of laboratory practices in science education?

(3). What are the opinions of pre-service science teachers' 
on the role and importance of laboratories in science education? In what ways, do laboratory courses have an impact on the views of pre-service science teachers regarding the role and importance of laboratory in science education?

\section{Materials and Methods}

Foregrounding science teachers' perceptions in elementary science laboratory work, this study add to the current understanding of pre-service science teachers' views of laboratory in elementary science teaching. In this regard, an understanding of pre-service teachers' notions of science laboratory work is established within a sociocultural context of Turkey.

\subsection{Context of the Study}

Turkey has a centralized science curriculum. The vision of recently revised National Science Curriculum is to educate students as scientifically literate individuals [21]. In this regard, what is stressed through the curriculum is the fact that when learners manage to grasp the basics of science, the barriers in daily life will be much more passable. The curriculum states that learning should be achieved by teaching scientific concepts to students with the help of designing experiments, experimenting, discovering, observing, interpreting and discussing the results of the experiments [21]. Instead of teaching science directly, it is much more important to teach the students how to search for and then reach the knowledge, a method which also emphasizes the importance of student's contemplating, problem solving and reaching knowledge through practical work. No matter how well-grounded the aims determined for practical work seem, the presence of the gap between this theoretical eulogiums and everyday realities is unignorable. The curriculum drives forward inquiry-based teaching; however teachers' traditional approaches, their own experiences and the present assessment systems build barriers before the implementation of that intended curriculum. As far as the nature of the centralized science curriculum is concerned, it could easily be noticed that this nature is shaped by the fact that one official textbook for both primary and elementary level which runs the logical and learning outcomes of the national curriculum prepared by a group of science educators, scientist and researchers. Depending on the official assignment the textbook has been given and the interoperability between the curriculum and the book, a great majority of the teachers can be said to be strictly loyal to the textbook. These textbooks propose plenty of practical experiments for students in order to lead them into thinking and problem solving as well as learning the science and its basics and require teachers to learn practical work and to benefit from the book as effectively and efficiently as possible.

In this regard, courses such as General Physics and General Chemistry Laboratory Applications are critical for learning basic concepts in laboratories. In teacher education curricula at Education Faculties, these courses are offered for the first year pre-service science teachers. The emphasis of General Physics Laboratory I and II courses has been on experiments regarding the basic concepts of mechanic and electric for 2 hours a week. Participants attended 20 weeks courses in total, in two semesters. General Chemistry Laboratory I and II courses were focused on techniques for laboratory work, safety rules, accidents and measures, laboratory materials and patterns of use in addition to laboratory activities provided in primary and elementary science curriculum for 20 weeks.

63 pre-service science teachers were enrolled in both general chemistry (20 weeks- for 2 hours a week) and general physics laboratory (20 weeks- for 2 hours a week) experiences concurrently in two semesters. Pre-service science teachers did experiment in groups of two persons. 
Teaching Procedure

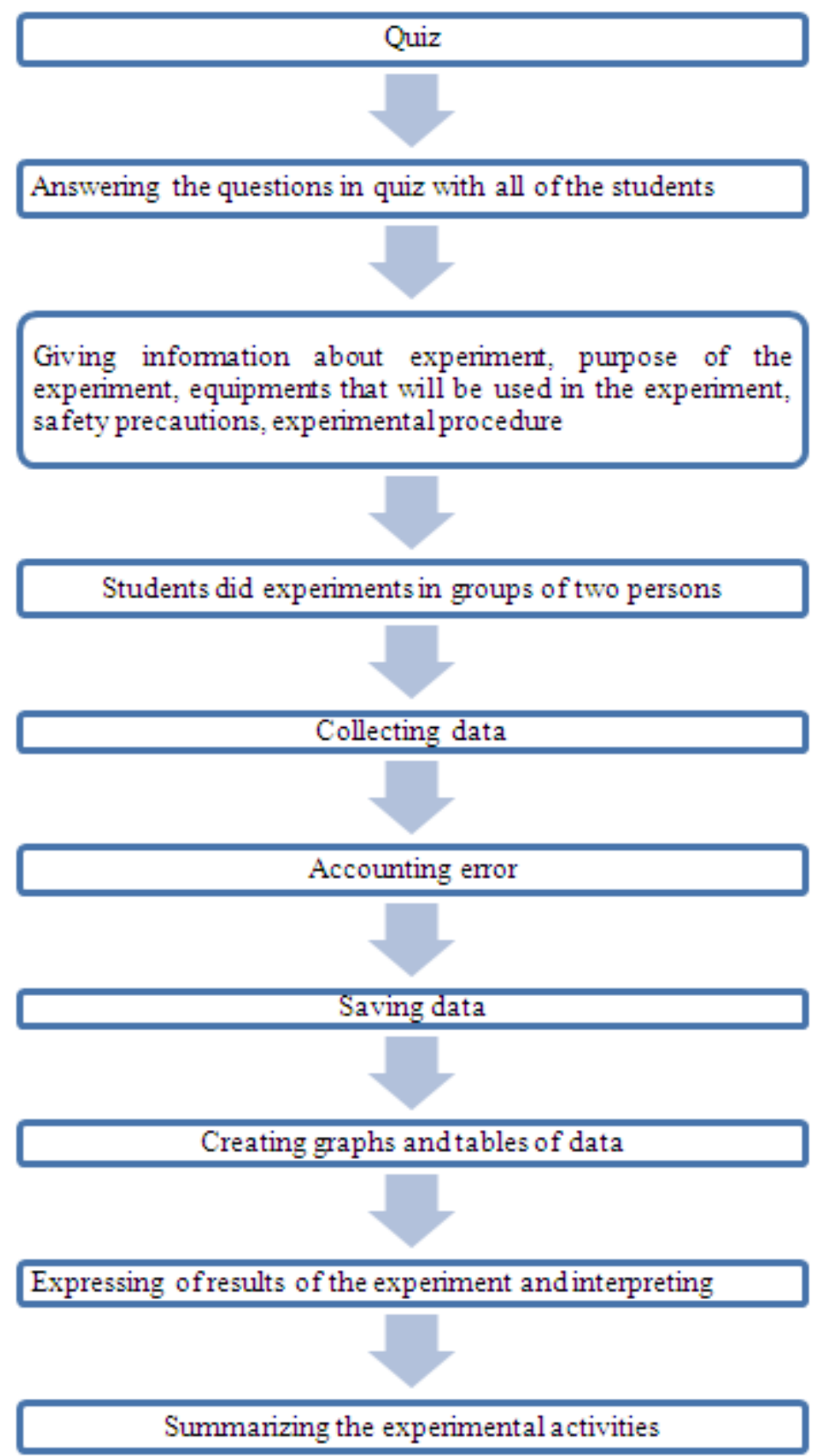

\begin{tabular}{|c|c|}
\hline $\begin{array}{l}\text { Experiments of the } \\
\text { General Chemistry } \\
\text { Laboratory I courses }\end{array}$ & $\begin{array}{l}\text { Giving information about safety rules } \\
\text { Giving information about rules of work in } \\
\text { laboratory } \\
\text { Giving information about equipment that will } \\
\text { be used in the experiment }\end{array}$ \\
\hline \multirow{6}{*}{ Laboratory I courses } & Separation methods \\
\hline & Density of matter (solid, liquid, gas) \\
\hline & Preparation solution \\
\hline & Gas laws \\
\hline & Properties of the acid and base \\
\hline & Oxidation and reduction reactions \\
\hline
\end{tabular}

Experiments of the General Chemistry

Laboratory II courses
Giving information about safety rules Giving information about rules of work in laboratory

Giving information about equipment that will be used in the experiment

Examining freezing point depression

The effect of concentration on rates of reaction The effect of temperature on rates of reaction Investigating chemical equilibrium

Examining of solubility and purification The colors of the indicator in acidic and basic Acid-base reactions Hydrolysis of the salt

Acid-base titration and determination of acetic acid in the grape vinegar 


\begin{tabular}{|c|c|}
\hline $\begin{array}{c}\text { Experiments of the General } \\
\text { Physics Laboratory I courses }\end{array}$ & $\begin{array}{c}\text { Giving information about safety rules } \\
\text { Giving information about rules of } \\
\text { work in laboratory } \\
\text { Giving information about equipment } \\
\text { that will be used in the experiment }\end{array}$ \\
\cline { 2 - 2 } & $\begin{array}{c}\text { Newton's laws of motion } \\
\text { Free-falling }\end{array}$ \\
\hline $\begin{array}{c}\text { Conservation of mechanical energy } \\
\text { Simple pendulum and physical } \\
\text { pendulum }\end{array}$ \\
\hline \begin{tabular}{c} 
Conservation of momentum \\
Calorimeter \\
\hline Determination of density with bottle \\
method
\end{tabular} \\
\hline Refractive index \\
\hline Centripetal force \\
\hline Moment of inertia \\
\hline
\end{tabular}

\begin{tabular}{|c|c|}
\hline $\begin{array}{c}\text { Experiments of the General } \\
\text { Physics Laboratory II } \\
\text { courses }\end{array}$ & $\begin{array}{c}\text { Giving information about safety rules } \\
\text { Giving information about rules of work } \\
\text { in laboratory } \\
\text { Giving information about equipment } \\
\text { that will be used in the experiment }\end{array}$ \\
\cline { 2 - 2 } $\begin{array}{c}\text { Ohm's law } \\
\text { Measurement of electromotive force and } \\
\text { resistance with graphics method }\end{array}$ \\
\hline $\begin{array}{c}\text { Capacitor } \\
\text { Kirchhoff's law }\end{array}$ \\
\hline $\begin{array}{c}\text { Measuring of mechanical equivalent of } \\
\text { calories } \\
\text { alternating current }\end{array}$ \\
\hline Transformer \\
\hline Magnetic field \\
\hline
\end{tabular}

\subsection{The Participants}

The study took place during 2013-2014 academic year in an elementary teacher education program in Turkey. 63 pre-service science teachers participated in the General Physics Laboratory I-II and General Chemistry Laboratory I-II courses, 63 (52 females, 11 males) pre-service science teachers administered the pre-test and post-test. As there was no concern for generalization due to the nature of qualitative research, participants were selected using purposive sampling.

\subsection{Research Method and Data-collection}

Using open-ended questions, the participants reflected their pre and post ideas with regard to practical work in laboratory courses. In order to determine the questions to be used in the instrument, four experts -a faculty member working in related subjects, two research assistants working in the laboratory and a chemistry teacher- were consulted for their views on the subject of laboratory, the main objectives of laboratory applications and the importance of laboratory in science education in the light of the related literature. In addition, in order to determine the clarity and the validity of the terms included in the instrument, a pilot study was administered on seven pre-service science teachers. The instrument was finalized using the results of the pilot study and the views of experts. Finally, pre-service science teachers were asked to write their views on the concept of laboratory, purpose of the laboratory, and the role and importance of laboratory practices in science education before and after the for all science laboratory sections as General Physics (20 weeks) and General Chemistry (20 weeks) Laboratory Applications courses. Pre-service science teachers took one pre-test and one post-test only (for all science laboratory sections).

The focus of the first open-ended question was on detecting the image of laboratory of the first year pre-service science teachers before attending any courses on laboratory application. The second open-ended question aimed to reveal the pre-service science teachers' perspectives on the purpose of the laboratory practices. And lastly, the third question was designed to uncover the ideas of first year pre-service science teachers' regarding the role and importance of laboratory practice in science education. The same questions were asked again to the same students after the laboratory courses (General Physics-20 weeks and General Chemistry-20 weeks) as posttests. At this time, it was expected that pre-service science teachers' views about laboratory, ideas about purpose of laboratory application, and their perception about the role and the importance of laboratory work in science education would change, develop or be reconstructed after attending General Physics and General Chemistry Laboratory Applications.

Application Time for Laboratory Courses

\begin{tabular}{|c|c|c|c|c|}
\hline & $\begin{array}{c}\text { General Chemistry Laboratory } \\
\text { I }\end{array}$ & $\begin{array}{c}\text { General Physics Laboratory } \\
\text { I }\end{array}$ & $\begin{array}{c}\text { General Chemistry Laboratory } \\
\text { II }\end{array}$ & $\begin{array}{c}\text { General Physics Laboratory } \\
\text { II }\end{array}$ \\
\hline Semester & First & First & Second & Second \\
\hline Week & 10 & 10 & 10 & 10 \\
\hline Hour & $10 \times 2=20$ & $10 \times 2=20$ & $10 \times 2=20$ & $10 \times 2=20$ \\
\hline Total & \multicolumn{2}{|c|}{20 weeks (40 hours) } \\
\hline
\end{tabular}




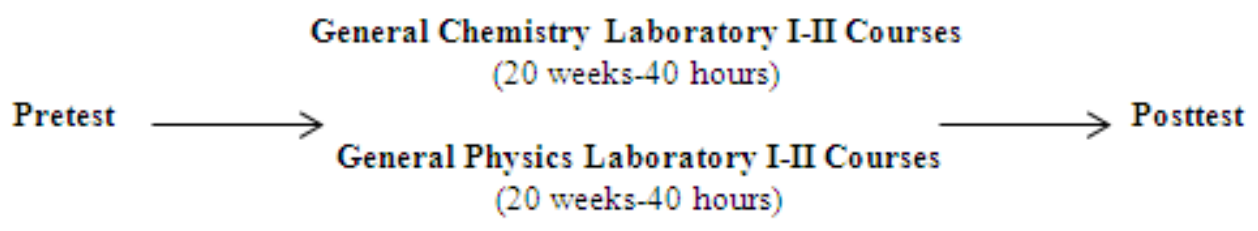

Application Scheme

\subsection{Data Analysis: The Focus of Interpretation}

Pre-service science teachers' answers to the questions were analyzed by using content analysis. To better understand the resulting data, the data was organized and interpreted. Content analysis of the data was conducted by: (1) data coding, (2) creation of categories, (3) regulation of the codes and categories, (4) identification and interpretation of findings. Percentages and the response frequencies of the placed categories were calculated. In addition, in order to identify common categories of pre-service science teachers' answers, they were constantly compared throughout the analysis process. The response codes belonging to pre-service teachers, common categories and frequencies and percentages of these categories were created. Therefore some pre-service teachers articulated more than one views for the same questions, some tables contain greater number of responses than the number of the participants.

There are three types of coding suggested by Strauss and Corbin [22] when the process of data coding is the case: the coding based on the concepts previously given, coding based on the concepts derived from the data, and the coding within a general framework. The present study will use the second type of coding, which is also in use for the research conducted on topics that lack a theoretical ground. Since there is not a theoretical structure to serve as a guide in the analysis of the data, the outcomes of the inductive analysis of the data is presented by the researcher. In the inductive analysis, the codes are directly derived from the data. In the category creation, which is the second phase, in order to determine the themes, the first step to be taken is to gather the data and then work on them. For thematic coding, the first step includes determining the similarities and differences of the emerged codes and then determining the themes that could gather the related codes. Attention was paid to whether the data collected under the theme created are logically linked or not. This was about 'internal consistency'. While all the themes are different from each other, they should be creating a meaningful unit within themselves and this is related to the 'external consistency'. In the last step, which is the regulation of the codes and categories, the researcher builds a system through which he/she could organize the data collected, then regulates the data according to this system and thus, it might be possible to interpret and identify the data according to certain facts. At this step, researcher spares no place for his/her own views and presents the data that he/she has collected and worked on.

\section{Findings}

How do pre-service science teachers define the concept of laboratory? In what ways, do laboratory courses have an impact on the definition of pre-service science teachers regarding the concept of laboratory?

Pre-service science teachers' opinions on the concept of laboratory have been analyzed and the comparative data is displayed in Table 1.

Table 1. Pre - service science teachers' opinions regarding the concept of laboratory

\begin{tabular}{ccccc}
\hline & \multicolumn{2}{c}{ Pre-test } & \multicolumn{2}{c}{ Post-test } \\
\hline Participants' Responses & N & $\%$ & N & $\%$ \\
\hline A place of application & 62 & 98,4 & 63 & 100,0 \\
\hline Method used in the laboratory & 47 & 74,6 & 48 & 76,2 \\
\hline Properties of laboratory & 26 & 41,3 & 20 & 31,7 \\
\hline The aim of the laboratory & 14 & 22,2 & 19 & 30,2 \\
\hline Other & 2 & 3,2 & - & -
\end{tabular}

Defining the concept of laboratory, pre-service teachers touched on the aspects including the methods used in the laboratory, properties of laboratory, the aim of the laboratory, and they also regarded laboratory as a place of application. So, the points that pre-service teachers made as defining the concept of laboratory were taken as separate categories to put systematically forward the statements of the pre-service teachers. What pre-service teachers most referred to were those which can be included within the category of 'the place of application'. And, 'the methods to be used' came the second. When compared to these two, the other categories including the properties of the laboratory or the aim of the laboratory were less touched by the pre-service teachers while defining the concept of laboratory.

The results of the posttests and pre-tests showed that the pre-service teachers defined laboratory as "a place of application", and thus this came out as the first category. Teachers' definitions were mostly application-related. For instance, they defined laboratory as a place where experiments or observations are carried out, a place that enables turning theory into practice, a place where you can observe the factuality of the daily life experiences and so on. Analyzing the pre-test and posttest results, it was seen that while 62 participants' answers could be assigned to this category before laboratory applications, after the instruction the number of participants increased to 63 . Both pre-test (31 participants) and posttest (26 participants) results showed 
that pre-service teachers tend to perceive application as experiment. They described the laboratory as a place where experiments are conducted. Even though it seems that this definition turned out to be less popular after the laboratory application, through a thorough analysis of the answers it could be seen that 17 pre-service teachers phrased laboratory as "the place where the theory turns into practice", which, in fact, was a more comprehensive one.

Another category regarding the definition of laboratory is "the methods used in the laboratory". While defining the concept of laboratory, pre-service teachers mentioned such methods as experiment, observation, discussion, $\mathrm{Q} / \mathrm{A}$, searching and so on. As the 41 participants' definitions in the pretest included experiment and observation, the 6 participants' definitions was consisted of items such as visualizing, learning through experience, searching and discussing. This was not different in the posttest results, either. 42 participants' definitions of the definitions included experiment and observation while 6 participants' definitions did learning through experience, searching and $\mathrm{Q} / \mathrm{A}$. The fact that the prospective teachers mentioned the student-centered teaching methods used in the laboratory is important because thus; students stress the role of the instructor as the guide.

Defining the laboratory, pre-service teachers also mentioned the properties of laboratory. Thus, this was determined as the third category. Pre-test results included more results related to the properties of laboratory (26 participants) when compared to the posttest results (20 participants). An extensive analysis of the results indicated that 20 participants' answers given in the pretest were related to hardware (materials, equipment) while this was 16 participants in the posttest. Moreover, 1 participant's answer given in pretests touched on the security concept and this rate was seen to have climbed up to 3 participants in the posttest results.

Lastly, pre-service teachers mentioned the aims of the laboratory in their definitions of the concept of laboratory; creating the last category as "the aim of the laboratory". What teachers believed to be the aims of laboratory were to understand correctly the information taught, to get proper results, to expand one's knowledge, to prove or refute a hypothesis, to acquire scientific process skills, to materialize the theoretical information, to learn easily and so on. The analyses pf pre-test and post-test results suggested that while 14 participants' definitions given before laboratory applications were relevant to this category, this figure increased to 19 participants after laboratory applications. Although there was an increase of $8 \%$, that this category was less addressed than all the others is regarded as negative when the fact that the students explained the aim of every single experiment they conducted in laboratory applications. It is believed that students' awareness of the aim of the experiment, which they explained during the laboratory application, is low.

What are the opinions of pre-service teachers' on the main purposes of laboratory practices in science education? In what ways, do laboratory courses have an impact on the views of pre-service science teachers regarding the main purposes of laboratory practices in science education?

Pre-service science teachers' opinions regarding the main objective of laboratory practices have been analyzed and the comparative data is displayed in Table 2.

Table 2. Pre-service science teachers' views on the main purposes of laboratory practices

\begin{tabular}{|c|c|c|c|c|c|c|}
\hline & & & \multicolumn{2}{|c|}{ Pre-test } & \multicolumn{2}{|c|}{ Post-test } \\
\hline \multicolumn{3}{|c|}{ Participant responses } & $\mathbf{N}$ & $\%$ & $\mathbf{N}$ & $\%$ \\
\hline \multirow{3}{*}{$\begin{array}{l}\text { Domains } \\
\text { of } \\
\text { Learning }\end{array}$} & \multicolumn{2}{|l|}{ Cognitive } & 16 & 25,4 & 19 & 30,2 \\
\hline & \multicolumn{2}{|l|}{ Effective } & 4 & 6,3 & 12 & 19,0 \\
\hline & \multicolumn{2}{|c|}{ Psychomotor } & 3 & 4,8 & 15 & 23,8 \\
\hline \multirow{9}{*}{$\begin{array}{l}\text { The } \\
\text { Quality of } \\
\text { Learning }\end{array}$} & \multicolumn{2}{|c|}{ Permanent learning } & 38 & 60,3 & 52 & 82,5 \\
\hline & \multicolumn{2}{|c|}{ Fast learning } & 5 & 7,9 & - & - \\
\hline & \multicolumn{2}{|c|}{ Decrease in rote-learning } & 2 & 3,2 & 3 & 4,8 \\
\hline & \multicolumn{2}{|c|}{ Effective learning } & 2 & 3,2 & 2 & 3,2 \\
\hline & \multicolumn{2}{|c|}{ Better understanding } & 2 & 3,2 & 2 & 3,2 \\
\hline & \multicolumn{2}{|c|}{ Learning with fun } & 1 & 1,6 & - & - \\
\hline & \multirow{3}{*}{$\begin{array}{l}\text { By using } \\
\text { these } \\
\text { methods }\end{array}$} & Materializing & 13 & 20,6 & 21 & 33,3 \\
\hline & & Visualizing & 11 & 17,5 & 9 & 14,3 \\
\hline & & $\begin{array}{l}\text { Experimental } \\
\text { learning }\end{array}$ & 5 & 7,9 & 3 & 4,8 \\
\hline \multicolumn{3}{|c|}{ Scientific Process Skills } & 27 & 42,9 & 23 & 36,5 \\
\hline \multicolumn{3}{|l|}{ Proof } & 10 & 15,9 & 5 & 7,9 \\
\hline \multicolumn{3}{|l|}{ Other } & 4 & 6,3 & 1 & 1,6 \\
\hline
\end{tabular}

The first category that was determined through the study is "Domains of Learning". It focuses on students' cognitive, affective and psychomotor learning domains. Upon analyzing the answers given within the scope of cognitive domain, it was seen that this sub-category embodied practices such as to gain knowledge, learn the laboratory, learn the materials of the laboratory or relate the knowledge to daily life issues and so on. It was observed that the number of pre-service teachers' statements about cognitive domain quietly closed each other in terms before (16 participants) and after (19 participants) laboratory applications. Pre-service teachers' answers before the laboratory application suggested that they generally focused on the items such as to gain knowledge or to learn laboratory and its materials (7 participants). For those given after the laboratory application, this stress was found to have decreased to a great extent (3 participants). On the other hand, the number of the prospective teachers who associated the purpose of laboratory applications with the daily life practices increased after laboratory applications (4 participants) when compared with pre-test results (2 participants). In other words, these results indicated that while pre-service teachers regarded the aim of laboratory practices only as gaining knowledge before the laboratory applications, their perception evolved to create a link between knowledge and the daily life practices during the 
laboratory applications. Most of the time pre-service teachers gave a negative start to the experimental activity to be performed in the laboratory as they were biased against it, asking 'what is the point of learning this?', which might inhibit their further learning. In terms of handling such biases, creating a link between the lab applications and daily life practices was seen to be flourishing in the test results.

Secondly, effective domain was examined and answers such as to learn to work individually or in a group, to gain experiences, to acquire the sense of curiosity, to develop one self, to make the students realize their own capabilities and so on were determined. Pre-service teachers' answers regarding the effective domain were found to have increased from 4 participants to 12 participants after the laboratory applications. The increase that emerged in the post-test results are attributed to students' carrying out experiments in the laboratory within groups of two or three which enabled them to interact with each other.

Pre-service teachers' answers such as to gain skills, to develop manual skills, to learn how to use the equipment, to move fast in the laboratory were determined within the scope of domains of learning and under the sub category of psychomotor domain. Pre-service teachers' psychomotor domain gains increased from 3 participants to 15 participants after the laboratory applications, which bring to minds that the students had not previously carried out any hands-on laboratory experiences or the experiments were only performed by teachers as a demonstration. The increases in the recent test results are important since they clearly show the efficacy of technical skill approach, which is paid attention throughout laboratory applications. Laboratory applications help students to learn basic practical skills [23]. An overview of the category of domains of learning might suggest that pre-service teachers' opinions regarding the purpose of laboratory practice were mostly concentrated on the cognitive domain, followed by affective and psychomotor domains.

Another aim of the laboratory application, according to the pre-service teachers, was to enhance the quality of learning. Within this scope, the other category determined in the study is the quality of learning. In terms of this category, pre-service teachers expressed their opinions regarding the quality of learning in the laboratories and the methods to be used to enhance quality. According to the answers of pre-service teachers, both pre-test and posttest were thoroughly examined, and it was found that the most frequently specified aims of laboratory applications included effective learning (2-2 participants), permanent learning (38-52 participants), decrease in rote-learning (2-3 participants), better understanding (2-2 participants), fast learning (5-0 participants) and learning with fun (1-0 participants). Along with the quality of learning, participants attached importance to the methods and techniques to be utilized in a lab setting to reach that desired quality. Their focus was generally on visualizing (11-9 participants), experimental learning (5-3 participants), materializing the theoretical information through application and observation

\section{(13-21 participants)}

Another category that pre-service teachers regarded as the aim of laboratory application is gaining science process skills (SPS). The pre-test (27 participants) and posttest (23 participants) results of the participants showed that they were generally of the opinion that through laboratory applications their science process skills may develop. Pre-service teachers were found to have focused more on observation component of SPS, which is also related to the previous category. According to pre-test results observation component (10 participants) included the following statements: to develop observation skills of the students, to conclude through observation, to reach quantitative data through qualitative observation, to explain the information through observation, to observe the reality, to perceive through observation and so on. Secondly, the scope of experiment component ( 9 participants) included items such as to conduct an experiment, to examine and learn the experiment, to explain the information through experiment and to learn how to conduct an experiment. And the deduction component ( 5 participants) included getting the experiment's outcomes, analyzing and determining these outcomes, to concretely have these outcomes and assessment. And the posttest results turned out to be more comprehensive, including experiment, observation and conclusion steps, as in the following: to understand and perceive the facts in the theory with the help of qualitative and quantitative observations, to understand where the information comes from and how, to prove the hypothesis of the experiments, to prove the correctness of the information that we learned in our daily life practices, to envision the cognitive process.

The fourth and last category is the proof. Pre-service teachers stated that proving is one of the main aims of laboratory applications. When pre-test and posttest results were compared, it was seen that the number of teachers who believed before lab applications (10 participants) that proof is one of the aims of lab applications significantly decreased after the applications (5 participants). This decrease is regarded as positive. Moreover, before lab applications, pre-service teachers simply defined the aim of lab application as to "prove", yet it was stated that after the applications some of the participants evolved their statements to "prove the accuracy of the information we get in our daily lives". These results bring to minds that the perspectives of pre-service teachers regarding the aims of lab applications were relatively narrow before the laboratory applications.

What are the opinions of pre-service teachers regarding the role and the importance of the laboratory in science education? In what ways, do laboratory courses have an impact on the views of pre-service science teachers regarding the role and importance of laboratory in science education?

The views of pre-service science teachers on the importance and place of laboratories in science education are displayed in Table 3. 
Table 3. The views of pre-service teachers regarding the importance of laboratories in science education

\begin{tabular}{|c|c|c|c|c|c|c|}
\hline & & & \multicolumn{2}{|c|}{ Pre-test } & \multicolumn{2}{|c|}{ Post-test } \\
\hline \multicolumn{3}{|c|}{ Participant Responses } & $\mathbf{N}$ & $\%$ & $\mathbf{N}$ & $\%$ \\
\hline \multirow{3}{*}{$\begin{array}{l}\text { Domains } \\
\text { of } \\
\text { Learning }\end{array}$} & \multirow{3}{*}{\multicolumn{2}{|c|}{$\begin{array}{l}\text { Cognitive } \\
\text { Effective } \\
\text { Psychomotor }\end{array}$}} & 10 & 15,9 & 12 & 19,0 \\
\hline & & & 3 & 4,8 & 6 & 9,5 \\
\hline & & & 1 & 1,6 & 1 & 1,6 \\
\hline \multirow{16}{*}{$\begin{array}{l}\text { The } \\
\text { Quality of } \\
\text { Learning }\end{array}$} & \multicolumn{2}{|c|}{ Permanent learning } & 21 & 33,3 & 29 & 46,0 \\
\hline & \multicolumn{2}{|c|}{ Meaningful learning } & 6 & 9,5 & 6 & 9,5 \\
\hline & \multicolumn{2}{|c|}{ Decrease in rote-learning } & 5 & 7,9 & - & - \\
\hline & \multicolumn{2}{|c|}{ Learning science } & 4 & 6,3 & - & - \\
\hline & \multicolumn{2}{|c|}{ Teaching with fun } & 4 & 6,3 & - & - \\
\hline & \multicolumn{2}{|c|}{ Consolidate knowledge } & 3 & 4,8 & - & - \\
\hline & \multicolumn{2}{|c|}{ Effective learning } & 2 & 3,2 & 3 & 4,8 \\
\hline & \multicolumn{2}{|c|}{ Easy learning } & 1 & 1,6 & 2 & 3,2 \\
\hline & \multicolumn{2}{|c|}{ Learning with fun } & 1 & 1,6 & 1 & 1,6 \\
\hline & \multirow{7}{*}{$\begin{array}{l}\text { By using } \\
\text { these } \\
\text { methods }\end{array}$} & Experiment & 12 & 19,0 & 16 & 25,4 \\
\hline & & Application & 10 & 15,9 & 16 & 25,4 \\
\hline & & Observation & 9 & 14,3 & 10 & 15,9 \\
\hline & & Visualizing & 6 & 9,5 & 16 & 25,4 \\
\hline & & Materializing & 2 & 3,2 & 7 & 11,1 \\
\hline & & $\begin{array}{l}\text { Learning by } \\
\text { doing }\end{array}$ & 3 & 4,8 & - & - \\
\hline & & $\begin{array}{l}\text { Searching by } \\
\text { oneself }\end{array}$ & 2 & 3,2 & - & - \\
\hline \multicolumn{3}{|c|}{ The Quality of Teaching } & 3 & 4,8 & 1 & 1,6 \\
\hline \multicolumn{3}{|c|}{ Scientific Process Skills } & 21 & 33,3 & 29 & 46,0 \\
\hline \multicolumn{3}{|l|}{ Proof } & 3 & 4,8 & 3 & 4,8 \\
\hline \multicolumn{3}{|l|}{ Other } & 2 & 3,2 & 3 & 4,8 \\
\hline
\end{tabular}

As one of the categories determined throughout the study, "Domains of Learning" focused on specifying the attainments of students in cognitive, effective and psychomotor domains within the scope of the importance of laboratories in science education. Firstly, it was seen that there was not a significant change when the answers of pre-service teachers regarding the importance of laboratories in science education were compared as before (10 participants) and after (12 participants) the laboratory applications regarding cognitive domain. It was found out that pre-test answers mostly included to have comprehensive knowledge of the subject, logicalness, to understand life, to apply the knowledge in life, to understand the scientific process while posttest answers mostly wandered around the axis of living creatures, nature and daily life and focused on how to obtain the knowledge and how to apply knowledge in daily life. It was seen that students' answers covered the definition of science and its characteristics. Students stated that science is logical and seeks to identify the universe and thus the nature and daily life. This is a highly important finding for displaying students' intermingled perception of laboratory and science.

As for the second subcategory, which is effective skills, here pre-service teachers listed the intended attainments in pretest (3 participants) as to increase curiosity, to focus on the lesson, to enhance the self-confidence of the student and in posttest (6 participants) as to draw students' attention to science, to be impressed, attention getting and self-development. Even less in number, this is in fact a sign that pre-service teachers did not deem laboratories as completely academic environments; in other words, effective skill acquisition which supports the structuring of knowledge is also important in laboratory applications.

Lastly, when the psychomotor acquisitions of students are analyzed, it was seen that one student, both before and after the laboratory application, put skills and the use of equipment into the psychomotor skills acquisition subcategory, considering technical skills.

An overview of the answers in the category "Domains of Learning" suggests that out of three acquisitions, cognitive one was centered. However, for cognitive skills to be acquired, both psychomotor and effective skills are necessary. The popularity of cognitive skills was worthy of attention since in fact, all the subcategories were expected to be valued almost equally.

The study showed that the statements regarding the importance of laboratories in science education accumulated in the category of "to enhance the quality of learning". This category is also important for embodying the methods to be used for such enhancing. When the pre and posttest results of pre service teachers were analyzed, it was seen that they mostly related the importance of laboratories to the quality of learning. It was also found that pre-service teachers who attached that much importance to this issue, proposed such methods as visualizing, materializing and application, observation and experiment both in pre and posttest answers and in the pre-test proposed to learn with experiencing and searching by oneself.

It was also found out that in "to enhance the quality of teaching" category, expressing the importance of laboratories in science education, pre service teachers also touched on the quality of teaching for 3 participants gave such answers as easy teaching, to be a good science teacher in pretest and 1 participant as to be a helpful teacher for their students.

As for another category, which is "to gain scientific process skills", it was detected that before ( 21 participants) and after (29 participants) the laboratory applications, pre-service teachers focused on basic process skills including experiment and observation and that there was an increase in the posttest. Also, it was found in the posttest results that they mentioned experimental process skills such as causative process skills and model creating.

In pre and posttest results, three students were found to express that laboratories are important in science education for proving, which then was determined as the last category. At this point, the scarcity in this category is regarded as positive when considering the fact that instead of completely close-ended and only proof-based experiments, open-ended applications which are based on hypothesis-testing and 
which enable students to discover; to make inventions, observations and research will be beneficial in raising the awareness of the important role that laboratories play in science education.

\section{Discussion, Conclusions and Recommendations}

\subsection{The Definition of the Laboratory}

It was found that while pre-service teachers were defining the laboratories, they generally deemed it as a place hosting the experiment or the observation, the place enabling to put the theory into practice and confirm the daily life knowledge, all of which were mostly related to application. Within the scope of all these, also in literature laboratory is defined as the place where students gained tangible outcomes by experiencing [1] and where they understood the concepts, principles and laws through the experiments they conducted [24]. Pre-service teachers also touched on such methods as experiment, observation, discussion, $\mathrm{Q} / \mathrm{A}$ and searching while defining the laboratory. The majority of the answers of pre-service teachers given both before and after the laboratory application included experiment and observation as the analysis suggested. Students defined the methods used in the laboratories as student-centered, which is highly important because of the emphasis this statement places on the active roles of students in the laboratory applications and roles of teachers as guides. Supporting the claims of pre-service teachers regarding student-centered activities, literature also proposes that teachers should not be the sole authority in the laboratory; but, the interactions between student and teacher, student and student, student and activity, student and equipment, student and laboratory are dearly important and should be established [6]. Pre-service teachers stated that making experiments, observations and research-investigation was developed by laboratory methods [25].

Pre-service teachers talked about the properties of the laboratory as well. It was seen that the majority of the answers given both before and after the laboratory applications included hardware (materials, equipment). In line with this fact, it was also stated that science lessons should be conducted in laboratories so as to motivate students into scientific studies and gain them research habits, and thus the laboratories should be opened in schools and developed [26-27-28-29]. However, the studies in the literature claimed that, even schools had laboratories; they did not have the necessary equipment for the intended education. It is truly important for a laboratory to have enough equipment for experiments to be conducted in the related fields e.g. physics, chemistry and biology. So the emphasis that pre-service teachers put on materials and equipment while defining the laboratories is in line with the literature. Moreover, it is also found out that after laboratory applications, pre-service teachers thought about security, too.
Literature states that pre-service teachers experience problems such as time, tools, curriculum and technological and pedagogical content knowledge [19]. At this point it is possible to say that in laboratories there should be posters, show cards or signs pointing to the security measures during the application. Pre-service teachers should be informed about the equipment and chemical substances that they were going to use before experiment and they should also explain them to their students. It is also believed that to provide pre-service teachers a guideline on security and security measures as well as the laboratory worksheet might be helpful.

\subsection{The Aim of the Laboratory Applications}

Pre-service teachers were found to focus on cognitive, affective and psychomotor attainments in explaining the aims of the laboratory applications. Analyzing the answers related to the cognitive domain, it was seen that while before laboratory applications pre-service teachers stated that the aim of the laboratory is to get knowledge, after the applications the opinions shifted to the interaction between the knowledge and daily life practices. Besides, it was seen in the latest test results that establishing such an interaction aiming to prevent the prejudices of pre-service teachers since they sometimes had such thoughts as 'what is the point in learning this?' at the very beginning of an experimental activity in the laboratory, which might possibly inhibit their further attainments, worked well. In parallel with the answers of the pre-service teachers, literature also confirms the fact that experimental science education helps students create a link between the daily life and science [30]. Literature also stresses that for those students who are of the opinion that laboratory plays an important role in creating the link with the daily life, laboratory experiments make it easier for them to understand the lesson [10]. Pre-service teachers expressed that knowledge was learned permanent and easily, learning process was fun and effective with laboratory method. In addition pre-service teachers expressed that laboratory applications was effective on hands-on activities, contact with daily life, making practice and concretize [25]. Literature was expressed that students found experiences in the laboratory exciting and interesting [15]. Within the scope of affective attainments, an increase was detected in the answers of pre-service teachers regarding these attainments before and after the laboratory applications and is attributed to the fact that students were conducting experiments in groups of two or three, interacting with each other. Although laboratories are often regarded as academic environments, the social interactions supporting the structuring of any kind of knowledge, is of great importance. This interaction surfaces simultaneously as the students are conducting their own duties [31]. Literature emphasizes that laboratory activities provide opportunities for meaningful and permanent learning in individual or in group work [18-32-33] and concretizing abstract and complex issues [34]. Literature also brought forward that the social interaction is 
an important factor for students to become successful and structure the knowledge [11]. Open-ended laboratory practices based on cooperation provide high level of motivation to the students and enable them to create their own thoughts and methods during the laboratory applications [13]. When it comes to the psychomotor domain, the components were skills, to gain hand skill, to use effectively the equipment, to learn to move fast and so on. An increase was detected in the above-mentioned after the laboratory applications. The increase detected in the latest test results is important since it puts forward the efficacy of technical skills approach which is valued during the experimental activities performed in the laboratories. With an overview of the domains of learning category, it can be said that before the laboratory applications, pre-service teachers' opinions regarding the aim of laboratory were mostly cognitive. In other words, based on learning; however, after the application this mostly shifted to affective and psychomotor attainments. Supporting the statements of the pre-service teachers, literature also says that experiment-based science education develops psychomotor skills [30-35] and hand skills [36]. Laboratory is considered as the best place to learn manipulative skills that include technical skills and functional aspects of performing laboratory task [55-56-57]. In parallel with the cognitive, affective and psychomotor skills mentioned by the pre-service teachers, literature also says that the aim is to develop students' cognitive skills such as logically and investigation-based thinking and affective skills such as cooperation and communication and psychomotor skills [16]. When the studies conducted on laboratory applications and yielding fruitful outcomes in terms of cognitive and affective domains [37] are analyzed cognitively, it was seen that laboratory activities enhanced academic success [2-3-38-39], contributed to interpretation of knowledge and deeper learning [40] and that experiments did contribute to the knowledge of the students [41]. It is clear that education gets better with laboratory activities [8-42]. When the successful outcomes of laboratory applications were analyzed affectively, it was seen that self-esteem and social behaviors of the students were positively affected [9-43]. Literature also suggests that in laboratory sessions which involve plentiful research and inquiry practices, teachers function as guides and students find the opportunity to improve their higher mental processing [44] and affective skills [45]. It was detected that some pre-service teachers expressed opinions regarding the quality of learning and the methods needed to be used to enhance that quality while they were talking about the aims of laboratory applications. In parallel with these findings, it is stated that laboratory encourages students for qualified learning [12]. Learning with fun, which had its place also in the statements of pre-service teachers, is favored in the literature by regarding it as that; a student-centered laboratory activity makes the learning process fun by whipping up the willingness and curiosity of the students towards the subject [46]. In the literature, pre-service teachers expressed that laboratory activities provide opportunities for making discovery, not memorizing by understanding learning and better understanding of theoretical course [47]. Another aim of the laboratory applications that pre-service teachers determined is scientific process skills. It was detected that pre-service teachers were of the opinion that through laboratory applications, scientific process skills can be developed, as their answers suggested. It was also detected that, before the applications they dwelled on observation, experiment and conclusion components of scientific process skills. However, in posttest results, more comprehensive statements, including experiment, observation and conclusion steps altogether, were found such as perceiving the theory through qualitative and quantitative observations, to understand how and where the knowledge comes from, to prove the hypothesis of the experiments, to confirm the knowledge gained through daily life, to envision the scientific process in mind. Also in literature, laboratory has been found to be contributing to the development of scientific process skills [48-49]. Pre-service teachers expressed that science and technology laboratory provides permanent learning with hands-on activities [48]. Moreover in the 2013 edition of science teaching program [21], it was stated that observation, measuring, classification, data recording, making hypothesis, all which belonged to skill acquiring domain, required to gain students those scientific process skills such as model creating, changing the variables, controlling and conducting experiment.

\subsection{The Importance of Laboratory in Science Education}

Explaining the importance of laboratories in science education, pre-service teachers used the definition of science and its characteristics. An overview of the answers of pre-service teachers in the "Domains of Learning" category showed that the focus was on cognitive skills. However, cognitive skills need to be supported with both psychomotor and affective skills. Yet, more or less, pre-service teachers touched on affective attainments, too, which suggest that they did not perceive laboratories as completely academic environments. Literature highlights the effective role of laboratories in developing the self-confidence of students [14].

The results showed that the majority of the pre-service teachers explained laboratory applications' importance as to enhance the quality of learning, as pretest and posttest results suggested. It is also seen that they proposed some methods crucial to such enhancement such as visualizing, materializing, and application, observation and experiment. Pre-service teachers talked not only about the learning dimension of learning but also the teaching dimension. A minority of teachers stated in the pre-test that thanks to the laboratory applications they believed that they could teach science easier to their students, that they could be successful and more beneficial science teachers. Supporting these statements regarding the good teacher model, literature also emphasizes that teachers should be sufficiently informed in their own field, following the scientific innovations, 
supporting their lessons with laboratory, well prepared for their class and motivating their students in their laboratory activities [10].

Another issue that pre-service teachers shed light on is scientific process skills. Even though the answers given within the scope of this domain increased after the laboratory applications, it was seen that pre-service teachers were mostly inclined to basic process skills such as experiment and observation. Moreover they also were found to be touching on causative process skills such as data evaluation and experimental process skills such as creating models. It is stated that with the help of research-based laboratory approach, students can gain high level of scientific process skills [50], can realize that, in fact, the scientific activities they perform belong to reality and that they can develop their abilities of scientific thinking [51]. In science teaching programs revised in 2013, it is stated that laboratory applications are necessary and beneficial for students to acquire such skills as observation, measurement, classification, data recording, making hypotheses, using the data and to gain scientific process skills such as model creating, changing and controlling the variables, conducting experiments and so on [21].

Briefly, it can be said that pre-service teachers' answers given to the three questions regarding the definition, aims and importance of the laboratories are found to be similar. However, the answers given before the laboratory applications were relatively more inclusive when compared to those afterwards. In other words, laboratory applications enabled pre-service teachers to regard the laboratories as a place well-equipped in terms of hardware and security measures, application-based for student-centered activities and laboratory activities enabled pre-service teachers to develop in three domains of learning; cognitive, affective and psychomotor and to enhance the quality of learning with student-centered methods, to gain scientific process skills and to adopt the importance of these applications for their future careers.

\section{REFERENCES}

[1] H. Özmen, N. Yiğit. Teoriden Uygulamaya Fen Bilgisi Öğretiminde Laboratuvar Kullanımı, Ankara, Anı Yayıncılık, 2005.

[2] C. Mc Donnell, C. O'Connor, M. K. Seery. Developing practical chemistry skills by means of student-driven problem based learning mini-projects. Chemistry Education Research and Practice, Vol.8, No.2, 130-139. 2007.

[3] U. Zoller, D. Pushkin. Matching Higher-Order Cognitive Skills (HOCS) promotion goals with problem-based laboratory practice in a freshman organic chemistry course. Chemistry Education Research and Practice, Vol.8, No.2, 153-171. 2007.

[4] D. H. Beach, H. M. Stone. Survival of the high school chemistry laboratory. Journal of Chemical Education, Vol.65, No. 7, 619-620. 1988.

[5] D. Hodson. Laboratory work as scientific method: Three decades of confusion and distortion. Journal of Curriculum Studies, Vol.28, No.2, 115-135. 1996

[6] Y. J. Dori, I. Sasson. Chemical understanding and graphing skills in an honors case-based computerized chemistry laboratory environment: The value of bidirectional visual and textual representations. Journal of Research in Science Teaching, Vol.45, No.2, 219-250. 2008.

[7] S. Çepni. Kuramdan Uygulamaya Fen ve Teknoloji Öğretimi, Ankara, Pegem A Yayıncılık, 2007.

[8] A. Hilosky, F. Sutman, J. Schmuckler. Is laboratory-based instruction in beginning college-level chemistry worth the effort and expense. Journal of Chemical Education, Vol.75, No.1, 100-104. 1998.

[9] R. Lazarowitz, R. Hertz-Lazarowitz, J. H. Baird. Learning science in a cooperative setting: Academic achievement and affective outcomes. Journal of Research in Science Teaching, Vol.31, No.10, 1121-1131. 1994.

[10] H. Tezcan. Lise kimya öğretiminde laboratuvar kullanımına ilişkin öğrenci görüşleri. Türk Eğitim Bilimleri Dergisi, Vol.4, No.1, 31-43. 2006.

[11] J. Lave, E. Wenger. Situated Learning: Legitimate Peripheral Participation, Cambridge, Cambridge University Press, 1991.

[12] J. J. C. Teixeira-Dias, H. Pedrosa de Jesus, F. Neri de Souza, M. Watts. Teaching for quality learning in chemistry. International Journal of Science Education, Vol.27, N.9, 1123-1137. 2005.

[13] T. Witteck, B. Most, S. Kienast, I. Eilks. A lesson plan on 'methods of separating matter' based on the Learning company approach - A motivating frame for self-regulated and open laboratory-work in introductory secondary chemistry lessons. Chemistry Education Research and Practice, Vol.8, No.2, 108-119. 2007.

[14] J. Carnduff, N. Reid. Enhancing undergraduate chemistry laboratories, pre-laboratory and post-laboratory exercises, examples and advice, Education Department. Royal Society of Chemistry, Burlington House, Piccadilly, London. 2003.

[15] S. W-Y. Lee, Y-C. Lai, H-T. A. Yu, Y-T. K. Lin. Impact of biology laboratory courses on students' science performance and views about laboratory courses in general: Innovative measurements and analyses. Journal of Biological Education, Vol.46, No.3, 173-179. 2012.

[16] A. Hofstein. The laboratory in chemistry education: Thirty years of experience with developments, implementation, and research. Chemistry Education Research and Practice, Vol.5, No.3, 247-264. 2004.

[17] M. B. Nakhleh. Chemical education research in the laboratory environment. How can research uncover what students are learning?. Journal of Chemical Education, Vol.71, No.3, 201-205. 1994.

[18] A. Hofstein, V. N. Lunetta. The laboratory in science education: Foundations for the twenty-first century. Science Education, Vol.88, No.1, 28-54. 2004.

[19] M. Kim, A. L. Tan. Rethinking difficulties of teaching inquiry-based practical work: Stories for elementary 
pre-service teachers. International Journal of Science Education, Vol.33, No. 4, 465-468. 2011.

[20] C-C.Tsai. Laboratory exercises help me memorize the scientific truths: A study of eighth graders' scientific epistemological views and learning in laboratory activities. Science Education, Vol.83, No.6, 654-674. 1999.

[21] MEB. İlköğretim Kurumları Fen Bilimleri Dersi (3-8. Sinıflar) Öğretim Programı, Ankara, Milli Eğitim Bakanlığı̆, 2013.

[22] A. Strauss, J. Corbin. Basics of Qualitative Research: Grounded Theory Procedures and Techniques, Newbury Park, CA: Sage, 1990.

[23] B. Tafa. Laboratory activities and students practical performance: The case of practical organic chemistry I course of Haramaya University. AJCE, Vol.2, No.3, 47-76. 2012.

[24] S. Çepni, A. R. Akdeniz, A. Ayas. Fen bilimleri eğitiminde laboratuvarın yeri ve önemi (III). Çağdaş Eğitim Dergisi, Vol.206, 24-28. 1994.

[25] C. Pekbay, F. Kaptan. Improvement of pre-service science teachers' awareness on the effectiveness of laboratory method in science education: A qualitative study. Karaelmas Journal of Educational Sciences, Vol.2, 1-11. 2014.

[26] A. E. Bozdoğan, N. Yalçın. İlköğretim fen bilgisi derslerindeki deneylerin yapılma sıklığı ve fizik deneylerinde karș1laşılan sorunlar. G. Ü. Kırşehir Eğitim Fakültesi Dergisi, Vol.5, No.1, 59-70. 2004.

[27] S. Uluçınar, A. Cansaran, A. Karaca. Fen bilimleri laboratuvar uygulamalarının değerlendirilmesi. Türk Eğitim Bilimleri Dergisi, Vol.2, No.4, 465-477. 2004.

[28] N. Uzun, N. Sağlam. Genetik konularının öğreniminde deney uygulamalarının akademik başarıya etkisi. Hacettepe Üniversitesi Eğitim Fakültesi Dergisi, Vol.28, 196-200. 2005.

[29] N. Yenice, A. G. Balım, G. Aydın. Biyoloji öğretmenlerinin laboratuvar dersine yönelik tutumları ve teknolojik yenilikleri izleme eğilimleri. Kastamonu Eğitim Dergisi, Vol.16, No.2, 469-484. 2008

[30] Ö. Ergin, E. Şahin-Pekmez, S. Öngel-Erdal. Kuramdan Uygulamaya Deney Yoluyla Fen Öğretimi, İzmir, Dinazor Kitabevi, 2005.

[31] D. I. Del Carlo, G. M. Bodner. The "Chemistry Mafia": The social structure of chemistry majors in laboratory. Electronic Journal of Science Education, Vol.13, No.1, 1-22. 2009.

[32] U. Böyük, S. Demir, M. Erol. Fen ve teknoloji dersi öğretmenlerinin laboratuvar çalışmalarına yönelik yeterlik görüşlerinin farklı değişkenlere göre incelenmesi. Türk Bilim Araștırma Vakfi Bilim Dergisi, Vol. 3, No.4, 342-349. 2010.

[33] M. Sarı. İlköğretim fen ve teknoloji derslerinin öğretiminde laboratuvarın yeri ve basit araç gereçlerle yapılan fen deneyleri konusunda öğretmen adaylarının görüşlerinin değerlendirilmesi. $2^{\text {nd }}$ International Conference on New Trends in Education and Their Implications, 27-29 April 2011, Antalya Turkey. 656-663. 2011.

[34] İ. Morgil, S. Güngör, N. Seçken. Proje destekli kimya laboratuvarı uygulamalarının bazı bilișsel ve duyusssal alan bileşenlerine etkisi. Türk Fen Eğitimi Dergisi, Vol.6, No.1, 89-107. 2009.

[35] B. Atasoy. Fen Öğrenimi ve Öğretimi, Ankara, Gündüz Eğitim ve Yayıncılık, 2002.

[36] C. Aydoğdu. Kimya eğitiminde yapılandırmacı metoda dayalı laboratuvar ile doğrulama metoduna dayalı laboratuvar eğitiminin öğrenci bașarısı bakımından karșılaștırılması. Hacettepe Üniversitesi Eğitim Fakültesi Dergisi, Vol.25, 14-18. 2003.

[37] O. Odubunmi, T. A. Balogun. The effect of laboratory and lecture teaching methods on cognitive achievement in integrated science. Journal of Research in Science Teaching, Vol.28, No.3, 213-224. 1991

[38] S. Bekar. Laboratuvar destekli fen bilgisi öğretiminin öğrenci başarısına etkisi. Yüksek lisans tezi. Gazi Üniversitesi Fen Bilimleri Enstitüsü, Ankara. 1996.

[39] B. Demirci. Că̆das fen bilimleri eğitimi ve eğitimcileri. Hacettepe Üniversitesi Eğitim Fakültesi Dergisi, Vol.9, 155-160. 1993.

[40] H. Kreitler, S. Kreitler. The role of the experiment in science education. Instructional Science, Vol.3, 75-88. 1974.

[41] S. Yaman, F. Öner. Lise fizik laboratuvarlarında kullanılan arac gereçlerin yeterlilik düzeyleri ve laboratuvar çalışmalarının değerlendirilmesi. Gazi Üniversitesi Kastamonu Eğitim Dergisi, Vol.11, No.3, 379-386, 2003.

[42] J. J. Lagowski. Reformatting the laboratory. Journal of Chemical Education, Vol.66, No1, 12-14. 1989.

[43] P. A. Okebukola. Cooperative learning and students' attitudes to laboratory work. School Science and Mathematics, Vol.86, No.7, 582-590. 1986.

[44] R. Spronken-Smith, R. Walker, J. Batchelor, B. O'Steen, T. Angelo. Evaluating student perceptions of learning processes and intended learning outcomes under inquiry approaches. Assessment \& Evaluation in Higher Education, Vol.37, No.1, 57-72. 2012.

[45] J. S. Wolf, J. B. Fraser. Learning environment, attitudes and achievement among middle-school science students using inquiry-based laboratory activities. Research in Science Education, Vol.38, No. 3, 321-341. 2008.

[46] H. Karaer. Yapılandırıcı öğrenme teorisine dayalı bir laboratuvar aktivitesi (kromatografi yöntemi ile mürekkebin bileşenlerine ayrılmas1). Kastamonu Eğitim Dergisi, Vol.15, No.2, 591-602. 2007.

[47] A. Arslan, F. Ogan-Bekiroğlu, E. Süzük, C. Gürel. Fizik laboratuvar derslerinin araştırma-sorgulama açısından incelenmesi ve öğretmen adaylarının görüşlerinin belirlenmesi. Türk Fen Eğitimi Dergisi, Vol.11, No.2, 3-37. 2014.

[48] Ö. Akgün. Öğretmen adaylarının fen ve teknoloji laboratuvarına ilişkin görüşleri ve bilim okur-yazarlığı. Yüksek lisans tezi. Fırat Üniversitesi Sosyal Bilimler Enstitüsü, Elazı̆̆. 2010

[49] A. Y1lmaz, F. İ. Morgil. Kimya öğretmenliği öğrencilerinin laboratuvar uygulamalarında kullandıkları laboratuvarların şimdiki durumu ve güvenli çalıșmaya ilișkin öğrenci görüşleri. Hacettepe Üniversitesi Eğitim Fakültesi Dergisi, Vol.15, 104-109. 1999.

[50] B. E. Myers, J. E. Dyer. Effects of investigative laboratory instruction on content knowledge and science process skill achievement across learning styles. Journal of Agricultural 
Education, Vol.47, No.4, 52-63. 2006.

[51] C. B. Russell, G. C. Weaver. A comparative study of traditional, inquiry-based, and research-based laboratory curricula: Impacts on understanding of the nature of science. Chemistry Education Research and Practice, Vol.12, 57-67. 2011.

[52] R. Millar, I. Abrahams. Practical work: Making it more effective. School Science Review, Vol.91, No.334, 59-64. 2009.

[53] R. Saad, S. BouJaoude. The relationship between teachers' knowledge and beliefs about science and inquiry and their classroom practices. Eurasia Journal of Mathematics, Science \& Technology Education, Vol.8, No.2, 113-128. 2012.

[54] C. S. Wallace, H. N. Kang. An investigation of experienced secondary science teacher's beliefs about inquiry: An examination of competing belief sets. Journal of Research and Science Teaching, Vol.41, 936-960. 2004.

[55] B. Campbell. Pupils' perceptions of science education at primary and secondary school. In H. Behrendt, et al. (Eds.) Research in Science Education- Past, Present and Future, Netherlands, Springer. 2002.

[56] R. M. Saat. Issues in maintaining continuity and progression of students' science learning. In A. Hussain, N. Idris (Eds.) Dimensions of Education, New Delhi, India, Gyan. 2010.

[57] H. M. Fadzil, R. M. Saat. Enhancing STEM education during school transition: Bridging the gap in science manipulative skills. Eurasia Journal of Mathematics, Science \& Technology Education, Vol.10, No.3, 209-218. 2014. 